\section{Factors Affecting Establishment of Sweet Cherry on Gisela 6 Rootstock}

\author{
Gerry H. Neilsen ${ }^{1}$, Denise Neilsen, Frank Kappel, Peter Toivonen, \\ and Linda Herbert \\ Agriculture and Agri-Food Canada, Pacific Agri-Food Research Centre, \\ Highway 97, Summerland, British Columbia, Canada, V0H 1 Z0
}

Additional index words. bark mulch, irrigation frequency, $\mathrm{P}$ fertigation, vigor, yield

\begin{abstract}
Cristalina and Skeena sweet cherry cultivars (Prunus avium L.) on Gisela 6 (Prunus cerasus $\times$ Prunus canescens) rootstock were maintained for the first four growing seasons in a randomized, replicated split-split plot experimental design with two main plot irrigation frequency treatments, the two cultivars as subplots and three soil management subsubplot treatments. The same amount of irrigation water was applied through four drip emitters per tree at either high (I1, four times daily) or low frequency (I2, once every second day) beginning in the second year. Three different soil management treatments were established the year of planting and included: 1) NK fertigation with a herbicide strip (control), or additionally; 2) maintenance of a $10-\mathrm{cm}$ thick bark mulch over the herbicide strip; and 3) annual fertigation of $20 \mathrm{~g}$ phosphorus (P) per tree per year immediately after bloom. I1 irrigation increased soil moisture $(0-$ to $20-\mathrm{cm}$ depth throughout each growing season. The I1 irrigation resulted in higher leaf and fruit concentrations of the immobile nutrients $P$ and potassium $(K)$ and larger trunk crosssectional area than $\mathbf{I} 2$ trees. I1 irrigation, in general, did not affect initial yield or fruit size. Fruit from 12 irrigation had higher soluble solids concentration (SSC), color, and total phenolic concentration at harvest in 2008 and lower titratable acidity (TA), firmness, and stem pull force suggesting an acceleration of fruit maturity. When compared with the control soil management treatment, $P$ fertigation resulted in leaves and fruit with higher $P$ concentrations, a higher 2008 crop yield, and a delay in 2008 crop maturity as indicated by lower harvest color and SSC and higher stem pull force. Mulch application, relative to control treatments, resulted in trees with higher vigor (but only with I1 irrigation) and leaf $K$ concentration and had few effects on initial fruit yield or quality. There were important differences in cultivar responses to treatments. 'Cristalina' vigor was lower than 'Skeena' whose fruit had lower firmness and pedicel retention than 'Cristalina'.
\end{abstract}

Development of high-density production systems on dwarfing rootstocks for sweet cherry is currently an area of active research (Lang, 2009; Robinson et al., 2008). These systems are advocated as inherently more profitable than low-density plantings but their economic success depends on rapid achievement of fruit production (Whiting et al., 2005). Therefore, cultural management strategies that improve tree establishment are important. Fertigation has been advocated for high-density apple because of its potential to improve tree performance by more closely synchronizing nutrient application and tree nutrient demand (Neilsen et al., 1999). Few studies on fertigation of sweet cherry have been reported (Neilsen et al., 2007) with even fewer studies on dripfertigation of sweet cherry (Neilsen et al.,

Received for publication 11 Feb. 2010. Accepted for publication 7 Apr. 2010.

Financial support was provided by the International Dwarf Fruit Tree Association, Okanagan Kootenay Cherry Growers Association, and Agriculture and Agri-Food Canada's Matching Investment Initiative (MII).

We acknowledge the technical assistance of Robert Brownlee, Istvan Losso, Bill Rabie, and several summer students.

${ }^{1}$ To whom reprint requests should be addressed; e-mail Gerry.Neilsen@agr.gc.ca. 2004a). Recent research on drip-fertigated apples has indicated an early yield response to annual phosphorus $(\mathrm{P})$ fertigation applied soon after bloom (Neilsen et al., 2008).

Similarly, there are limited irrigation strategies specific to sweet cherry, although it is recognized that cherries should be well irrigated early in the growing season to avoid plant water deficits (Hanson and Proebsting, 1996). No distinction is made between irrigation strategies for establishing and fruiting sweet cherry trees, although for apple, moisture stress has been identified as a potentially important limitation to establishment and precocity of apple trees (Neilsen and Yorston, 1991). Recent research has indicated improved growth and yield of sweet cherry after use of in-row synthetic polypropylene groundcovers (Yin et al., 2007) with some of the benefits of their use attributed to improved soil moisture content (Núñez-Elisea et al., 2004). Surface mulches have been advocated in the initial years of high-density apple orchards as a method of improving soil quality and tree vigor and yield (Neilsen et al., 2003). Recently, the advantages of multiple, small, daily nutrient and water applications have been suggested as a method of improving plant growth and nutrient uptake (Silber et al., 2003), but this technique has not been assessed for sweet cherry.

An experiment was thus established to determine the effects of irrigation frequency,
$\mathrm{P}$ fertigation, and mulching on the initial growth of the sweet cherry cultivars Cristalina and Skeena on the dwarfing rootstock Gisela 6.

\section{Materials and Methods}

An experimental orchard of 'Cristalina' and 'Skeena' sweet cherry on Gisela 6 (Prunus cerasus $\times$ Prunus canescens) rootstock was planted in Mar. 2005 at the Pacific AgriFood Research Center in Summerland, British Columbia, Canada. The spacing was $2 \mathrm{~m}$ (between trees in a row) $\times 4 \mathrm{~m}$ (between rows) for a planting density of 1250 trees/ha. The block was laid out to accommodate a randomized, replicated split-split plot experimental design incorporating two main plot irrigation treatments, the two cultivars as subplots and three soil management treatments as subsubplots (four trees each) with six replicate rows. The main plot irrigation treatments did not begin until the second year (2006). In the planting year (2005), normal, daily drip irrigation was applied over the whole block with the duration of irrigation applied each day scheduled according to the previous day's evaporative demand as measured by an atmometer (ET Gauge Co., Loveland, CO). Daily irrigation quantities were adjusted to compensate for the previous day's estimated water use (Parchomchuk et al., 1996). Beginning in 2006 and throughout the 2008 growing season, the same amount of water, as determined by an atmometer, was applied but at two different frequencies (I1 and I2). High-frequency irrigation (I1) supplied $25 \%$ of daily irrigation four times daily (every $6 \mathrm{~h}$ ) at $0900,1500,2100$, and $0300 \mathrm{HR}$. For lowfrequency irrigation (I2), the same amount of water was applied once every $2 \mathrm{~d}$ at $0900 \mathrm{HR}$. In the establishment year, irrigation was applied through $4 \times 4-\mathrm{L} \cdot \mathrm{h}^{-1}$ emitters located within $0.15 \mathrm{~m}$ of the tree row and tree on both sides of the tree. From 2006 to 2008, emitters were located further from the tree, occupying a square pattern of $0.6-\mathrm{m}$ spacing centered on the tree with two emitters on each side of the tree row. Randomized subplots within each main plot comprised 10 'Skeena' and 'Cristalina' trees sufficient to incorporate three soil management subsubplots with shared guard trees. Soil treatments were established in the first year and included 1) an unamended control; 2) a 10-cm thick wood waste mulch maintained over a 2-m wide strip centered on the tree row; and 3) an annual fertigated $\mathrm{P}$ treatment of $20 \mathrm{~g} \mathrm{P} /$ tree applied as ammonium polyphosphate $(10 \mathrm{~N}-34 \mathrm{P}-0 \mathrm{~K}), 20$ to 25 May 2005 and just after bloom on 10, 9, and 12 May 2006 to 2008 , respectively. The coarsetextured mulch was locally available from BC forestry operations and was comprised of small branches ground to $\approx 1 \mathrm{~cm}$. The material has a low dry weight nutrient content (8 $\mathrm{g}$ nitrogen/ $\mathrm{kg}, 1 \mathrm{mg} \mathrm{P} / \mathrm{kg}$, and $3 \mathrm{mg}$ potassium $/ \mathrm{kg}$ ) and was selected based on its ready availability and its soil moisture conservation potential. The two central trees within each subsubplot were used as measurement trees, leaving a guard tree between each adjacent plot within the row. The six replicate treatment rows were bordered by a guard row, which surrounded the plot. 
Nitrogen $(\mathrm{N})$ was fertigated at $28 \mathrm{mg} \mathrm{N} / \mathrm{L}$ as calcium nitrate $(15.5 \mathrm{~N}-0 \mathrm{P}-0 \mathrm{~K})$ throughout the block. In 2005, N was applied 10 June to 22 July and again 17 Aug. to 1 Sept. to avoid $\mathrm{N}$ limitations in first year. Subsequently, N was applied for $\approx 8$ weeks immediately after application of P from 11 May to 17 July 2006, 11 May to 17 July 2007, and from 13 May to 3 July 2008. To avoid the development of low leaf potassium $(\mathrm{K})$ concentration, which has been observed to occur on drip-irrigated sweet cherry on dwarfing rootstock grown on coarsetextured soils after 3 years (Neilsen et al., 2007), $20 \mathrm{~g} \mathrm{~K} /$ tree/year was fertigated as potassium chloride $(0 \mathrm{~N}-0 \mathrm{P}-50 \mathrm{~K}) 11$ June to 17 July 2007 and 8 June to 3 July 2008. Throughout the study, a 2-m wide weed-free herbicide strip was maintained under the trees. Standard commercial production practices were used to control insects and diseases as required [British Columbia Ministry of Agriculture and Lands (BCMAL), 2007]. No gibberellic acid was applied in the planting.

The experimental site was located on a Skaha loamy sand (Wittneben, 1986), an Aridic Haploxeroll, extensively planted to orchards in southern British Columbia. Coarse-textured soils such as these are characterized by limited nutrient and water-holding capacities. The volumetric moisture content for this soil averaged $18 \%$ by volume at field capacity ( 0.1 bars) and $8 \%$ at the permanent wilting point (15 bars).

Data collected for all measurement trees $(\mathrm{n}=144)$ included trunk diameter at $0.3 \mathrm{~m}$ above the graft union. These data were collected annually during dormancy from November to January. From these measurements, trunk cross-sectional area (TCSA) after each growing season was calculated. Composite samples comprising 30 leaves per plot (two trees) were collected from the midthird portion of extension shoots for both cultivars at harvest of 'Skeena' in July 2005 to 2007 and separately at the harvest of each cultivar in 2008. Nitrogen content was determined on a 0.125-g sample using Leco $\mathrm{N}$ dry combustion (St. Joseph, MI), whereas P and K were determined by inductively coupled argon plasma spectrophotometry (Spectro Modula; Spectro Analytical Instruments, Kleve, Germany) on 0.5 -g samples, dry-ashed, and dissolved in $1.2 \mathrm{M}$ $\mathrm{HCl}$.

The first fruit appeared in 2006 and the small number of fruit that year was counted at commercial harvest on 6 July for 'Cristalina' and 26 July for 'Skeena'. The 2007 crop was smaller than expected because of cold damage associated with minimum temperatures below $-20{ }^{\circ} \mathrm{C} 28$ to 29 Nov. 2006 and potentially damaging frosts 1 to $3 \mathrm{Apr}$. and 11 to $12 \mathrm{Apr}$. in 2007 with a minimum temperature of $-5.1^{\circ} \mathrm{C}$ on 3 Apr. Both cultivars were between side green and green tip during these frost events and when full bloom occurred in the first week of May, many blossoms appeared abnormal (small and stunted). At commercial harvest, 29 June for 'Cristalina' and 11 July for 'Skeena' in 2007, all fruit were counted and weighed. The 2008 harvest was the first crop sufficiently large for detailed fruit assessment at harvest and was collected and weighed at commercial harvest 9 and 22 July, respectively, for 'Cristalina' and 'Skeena'.

A randomly harvested 100-fruit subsample from each treatment and replicate was used to determine average fruit weight and the number of fruit splits. Color was determined on 20 fruit using the Michigan State University 1 to 5 scale chart (Michigan State University, East Lansing, MI). Juice soluble solids concentration (SSC) was determined by digital refractometry (Model PR-101; AD Scientific Instruments, Keene, NM) on juice extracted from this subsample. Titratable acidity (TA) was also determined on the juice by titration to an $8.1 \mathrm{pH}$ end point by an autotitrator (Model 719 S Titrino; Metrohm, Herisa, Switzerland). Fruit firmness (FirmTechII; Bioworks, Stillwater, OK) and stem pull force (Dart FGV-5X digital force gauge; Shimpo America Corp., Ithasca, IL) were measured on a 20 -fruit subsample before juicing.

A 60-fruit sample was collected, pitted, blended into an homogenous slurry, and freeze-dried before determination of $\mathrm{N}$ concentration on $0.135 \mathrm{~g}$ and $\mathrm{P}$ and $\mathrm{K}$ concentration on 0.5 -g samples by the methods and instrumentation previously described for leaf samples and expressed on a fresh weight basis.

Total phenolics were extracted from a $0.2-\mathrm{g}$ freeze-dried cherry powder sample through addition of $5 \mathrm{~mL} 0.1 \% \mathrm{HCl}$ in methanol. After the addition of the acidified methanol, the sample was then vortexed and placed on an orbital shaker for $1 \mathrm{~h}$ set at a rate of $330 \mathrm{rpm}$ at room temperature $\left(22^{\circ} \mathrm{C}\right)$. The samples were again vortexed and then centrifuged at $24,000 \mathrm{~g}$ for $20 \mathrm{~min}$ at room temperature in an Allegra 64R centrifuge (Beckman Coulter Canada Inc., Mississauga, Ontario, Canada). The supernatant was then filtered through glass microfiber filters (Whatman GF/D) with samples retained at $-80{ }^{\circ} \mathrm{C}$ until measured for total phenolics through the Folin-Ciocalteu assay. A $0.5-\mathrm{mL}$

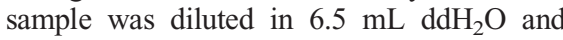
mixed thoroughly to ensure a homogenous solution. A $0.5-\mathrm{mL}$ volume of Folin-Ciocalteu reagent (Sigma-Aldrich Canada Limited, Mississauga, Ontario, Canada) was added and mixed thoroughly. After $3 \mathrm{~min}, 1 \mathrm{~mL}$ of saturated sodium carbonate solution was added with $1.5 \mathrm{~mL}$ of $\mathrm{ddH}_{2} \mathrm{O}$ to bring the volume to $10 \mathrm{~mL}$, mixed, and retained at room temperature for $1 \mathrm{~h}$. A method blank was also prepared using $0.5 \mathrm{~mL}$ of $0.1 \% \mathrm{HCl}$ in methanol instead of sample extract. Absorbance at $725 \mathrm{~nm}$ was read using a Cary 100 Bio ultraviolet-Vis spectrophotometer (Varian Canada, Mississauga, Ontario, Canada). Total phenolic results were expressed as $g$ per $g$ dried tissue using an equation obtained from analysis of standard quantities of gallic acid.

Soil moisture was measured using time domain reflectometry each year beginning after the initiation of differential irrigation treatments in 2006 (Topp and Reynolds, 1998). Depth-integrated measurements (0 to $20 \mathrm{~cm}$ ) were made approximately weekly during the main irrigation season from May to Sept. 2006 to 2008 at 24 locations [two cultivars $\times$ two irrigation treatments $\times$ two soil management treatments (control and mulch) $\times$ three replications]. Probes were consistently located $0.3 \mathrm{~m}$ from the tree, midway between the two emitters on the south side of the tree, and measurements were made just before the 0900 HR irrigation.

Analysis of variance was performed on all response variables, except soil moisture measurements, as a split-split plot experimental design with irrigation treatments as main plot units, cultivars as subplots, and three soil management treatments as subsubplots with six replicates. Soil moisture values were similarly analyzed for each measurement day but with only two soil management subsubplots and three replicates. Percent splits were arcsine square root-transformed before analyses. All statistical analyses were undertaken using the general linear model procedure (SAS, 1989).

\section{Results and Discussion}

Irrigation frequency. Average volumetric soil moisture content over the top $20-\mathrm{cm}$ depth was usually significantly higher with high-frequency irrigation (four times per day) than when irrigated every second day (I2). Exceptions included a dry period for both treatments from mid-June to early July 2007 and during cool, wet periods in May to June and late Aug. 2008 (Fig. 1). These moisture measurements were timed throughout 2006 to 2008 to be undertaken on days immediately before I 2 irrigation, thus maximizing possible differences between I1 and I2. The largest soil moisture fluctuations also occur in the surface layers of these irrigated soils. Midday stomatal conductance readings were significantly higher at I1 on five of 12 occasions when measured periodically in midsummer (July to August) throughout the 2006 to 2008 growing seasons (data not shown).

Tree vigor, as indicated by TCSA, was characterized by a significant interaction between irrigation and soil management treatment at the end of each of the four growing seasons from 2005 to 2008 (Fig. 2). I1 irrigation, however, was always associated with larger trees with the effects starting the first year after imposition of the different irrigation treatments and increasing in magnitude each year thereafter. The performance of the soil management treatments, however, differed between I1 and I 2 and are discussed further in the soil management section.

Of the major nutrients $\mathrm{N}, \mathrm{P}$, and $\mathrm{K}, \mathrm{K}$ was most affected by irrigation frequency (Table 1 ). From 2005 to 2008, leaf K concentration was always increased at I1 despite a significant interaction of irrigation frequency with soil management treatment in 2006 and with cultivar in 2007. Leaf P concentration was also increased by irrigation frequency, as indicated by higher average concentrations at I1, 2007 to 2008 . Leaf $\mathrm{N}$ concentration was characterized by a significant irrigation frequency by soil management treatment interaction, 2006 to 2008, but there was no consistent pattern of increase or decrease associated with either I1 or I 2 across years and soil management treatments.

There were few effects of irrigation frequency on crop production (Table 2) despite 


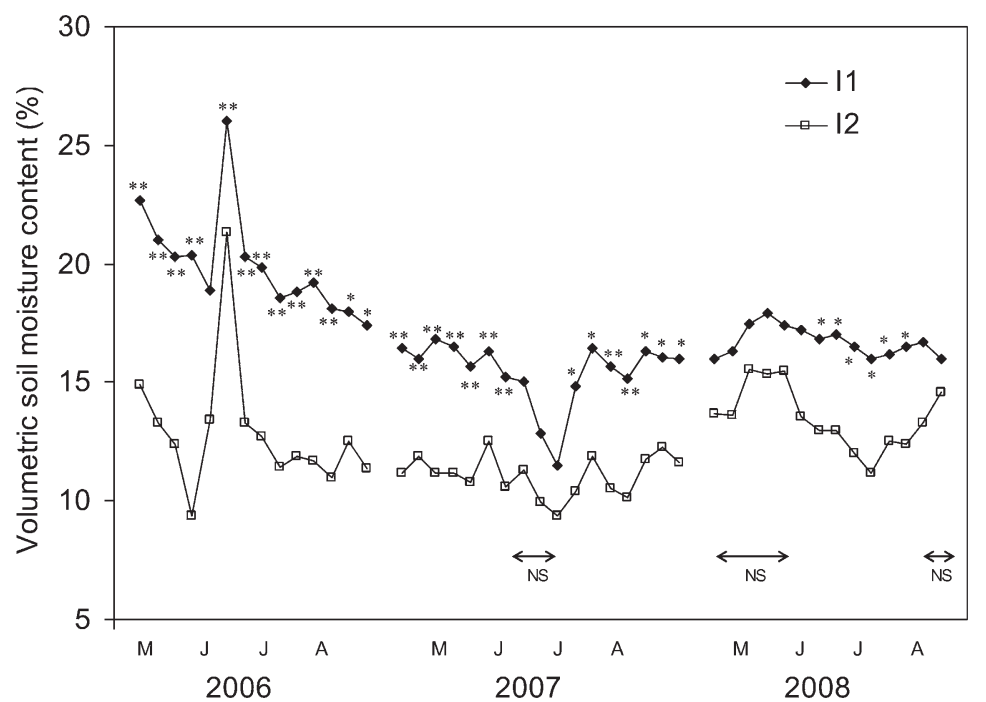

Fig. 1. Average volumetric soil moisture content, 0 - to 20 -cm depth, for I1 (4× daily) and I2 (every second day) irrigation treatments applying the same quantities of water, 2006 to 2008 growing seasons. Significance level at $P \leq 0.05(*)$ or $P \leq 0.01(* *)$ indicated above (or below) I1 values or not significantly different (NS).

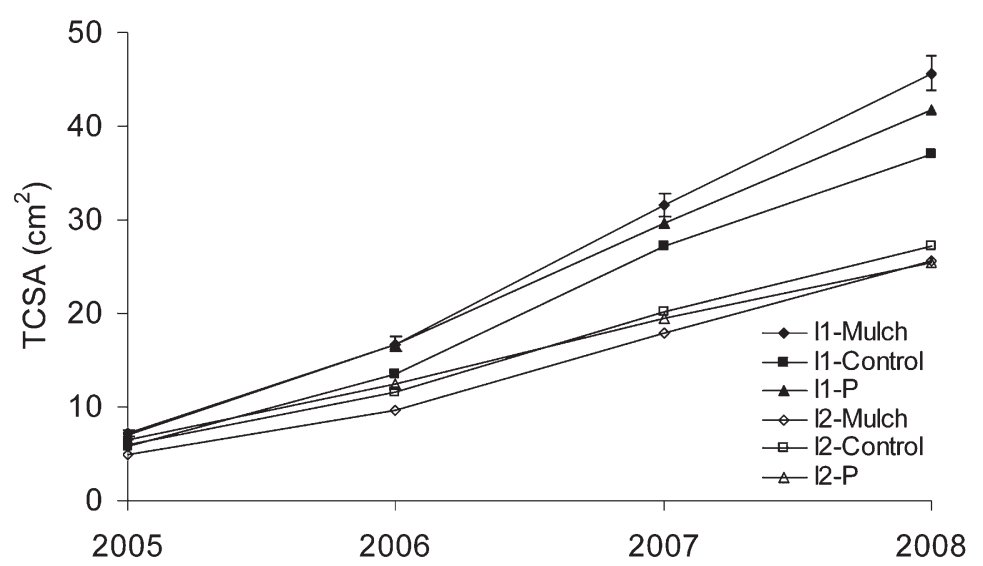

Fig. 2. Average trunk cross-sectional area (TCSA) as affected by irrigation and soil management treatment at the end of each growing season, 2005 to 2008. Irrigation treatments include I1 (4× daily) or I2 (every second day) applying the same quantities of water. Interaction SE was the same for all treatments and indicated on the top curve unless smaller than symbols.

large tree size associated with frequent irrigation (I1). Minimal cropping occurred in 2006 to 2007 with fruit number increased in 2006 for I2-irrigated trees and per tree yield increased in 2007 for trees receiving $\mathrm{P}$ fertigation and $\mathrm{I} 2$ irrigation (significant irrigation $\times$ soil management interaction). Fruit size (2007 to 2008) and per tree yield in 2008 were unaffected by irrigation frequency. Fruit quality was, however, strongly affected by irrigation frequency in 2008, when more than a minimal crop was harvested and quality was assessed (Table 3). Decreasing the frequency of irrigation (I2) appeared to accelerate crop maturity as indicated by increased skin color and SSC and decreased TA, fruit firmness, and stem pull force relative to fruit on trees irrigated four times daily. In contrast, fruit $\mathrm{N}, \mathrm{P}$, and $\mathrm{K}$ concentrations were higher for fruit on I1-irrigated trees, whereas the opposite trend was apparent (decreased concentration at I1) for fruit total phenolic con- centration (Table 3 ). The incidence of fruit splitting in 2008 was low (less than $2 \%$ ) and unaffected by irrigation treatment.

Use of a growing season soil moisture measurement scheme designed to maximize soil moisture differences between irrigation treatments, indicated that throughout 2006 to 2008 , soil moisture content over the surface 0 to $20-\mathrm{cm}$ depth was frequently decreased to $10 \%$ to $15 \%$ volumetric moisture content at I 2 from the $15 \%$ to $20 \%$ range generally observed for daily irrigation (I1). Such periodic moisture reductions were sometimes reflected in lower midday summer stomatal conductance readings and were sufficient to reduce TCSA (and by inference, canopy volume) of I 2 trees to $\approx 60 \%$ of I1 trees by the end of 2008,3 years after treatment imposition. It is therefore implied that on coarse-textured, rapidly draining soils, as used in this study, high-frequency irrigation would be advantageous for rapid establishment of the canopy framework for sweet cherry on dwarfing rootstocks. It is noteworthy that cherry on Gisela 6 rootstock responded to reductions in soil moisture content in the surface $20 \mathrm{~cm}$ of the soil. Few measurements have been made of cherry root distribution with depth for dwarfing rootstocks such as Gisela 6. For similar coarse-textured soils, the average depth for drip-fertigated apple trees after 7 years was $18 \mathrm{~cm}$ and $25 \mathrm{~cm}$ for trees on M.26 and M.9 rootstocks, respectively (Neilsen et al., 1997). It is generally believed that cherries, particularly early in the growing season, should be irrigated to avoid plant water deficits (Hanson and Proebsting, 1996). Our results indicate that cherry vegetative growth on dwarfing rootstocks is also sensitive to moisture content early in the establishment period of a planting. The I1 moisture regime fluctuated at soil water potentials much closer to 0.1 bar field capacity relative to I2. Useful future research would be an examination of water potential thresholds below which cherry growth and productivity would be adversely affected. Such data would be transferable across sites with different soil textures. Additional evidence of cherry sensitivity to moisture regime was indicated by earlier research, which indicated that canopy volume of 'Lapins' sweet cherry on the dwarfing Gisela 5 rootstock was reduced relative to sprinkler-irrigated trees after 4 years of daily drip irrigation, which wet only a portion of the orchard floor (Neilsen et al., $2004 \mathrm{~b}$ ). Improved tree vigor of 'Regina' sweet cherry on Gisela 6 rootstock under polypropylene groundcover (Yin et al., 2007) could be attributed, in part, to improvements in soil moisture content (Núñez-Elisea et al., 2004).

There is little evidence from leaf N, P, and $\mathrm{K}$ concentrations that reduced vegetative vigor associated with I 2 had inadequate nutrition as its major cause. Midsummer leaf concentrations were generally within the 19 to $30 \mathrm{~g} \mathrm{~N} / \mathrm{kg}$ dry weight $(\mathrm{dw})$ and 13 to $16 \mathrm{~g} \mathrm{~K} / \mathrm{kg} \mathrm{dw}$ adequacy range and above the $1.5 \mathrm{~g} \mathrm{P} / \mathrm{kg} \mathrm{dw}$ threshold recommended for sweet cherry in British Columbia (BCMAL, 2007). An exception was a leaf $\mathrm{K}$ concentration of $\approx 12 \mathrm{~g} \mathrm{~K} / \mathrm{kg}$ $\mathrm{dw}$ measured for I2-irrigated trees receiving $\mathrm{P}$ in 2006. It is noteworthy that $\mathrm{K}$ and $\mathrm{P}$ were the nutrients most affected by irrigation treatments because these nutrients move to the plant root primarily by diffusion (Barber, 1984), suggesting the I 2 irrigation regime sufficiently reduced soil to root diffusion to adversely affect tree uptake of especially $\mathrm{K}$ and also $\mathrm{P}$.

Yield production was minimal in the experimental plots in 2006 to 2007 with spring frost in Apr. 2007 reducing yield that year so that only in 2008 was a first, but relatively light $(4.5 \mathrm{~kg} /$ tree $)$ crop produced. Despite minor positive effects of water stress (I2) on yield initiation in the first 2 fruiting years, cumulative yield during the study period was dominated by the 2008 yield, which was unaffected by irrigation treatment. Previous research indicates that major reductions in size of trees on dwarfing rootstocks will eventually detrimentally affect sweet cherry yield (Neilsen et al., 2007). Quality of the initial 
Table 1. Average mid-July leaf nitrogen $(\mathrm{N})$, phosphorus $(\mathrm{P})$, and potassium $(\mathrm{K})$ concentration as affected by irrigation frequency, soil management treatment, and sweet cherry cultivar, 2005 to 2008.

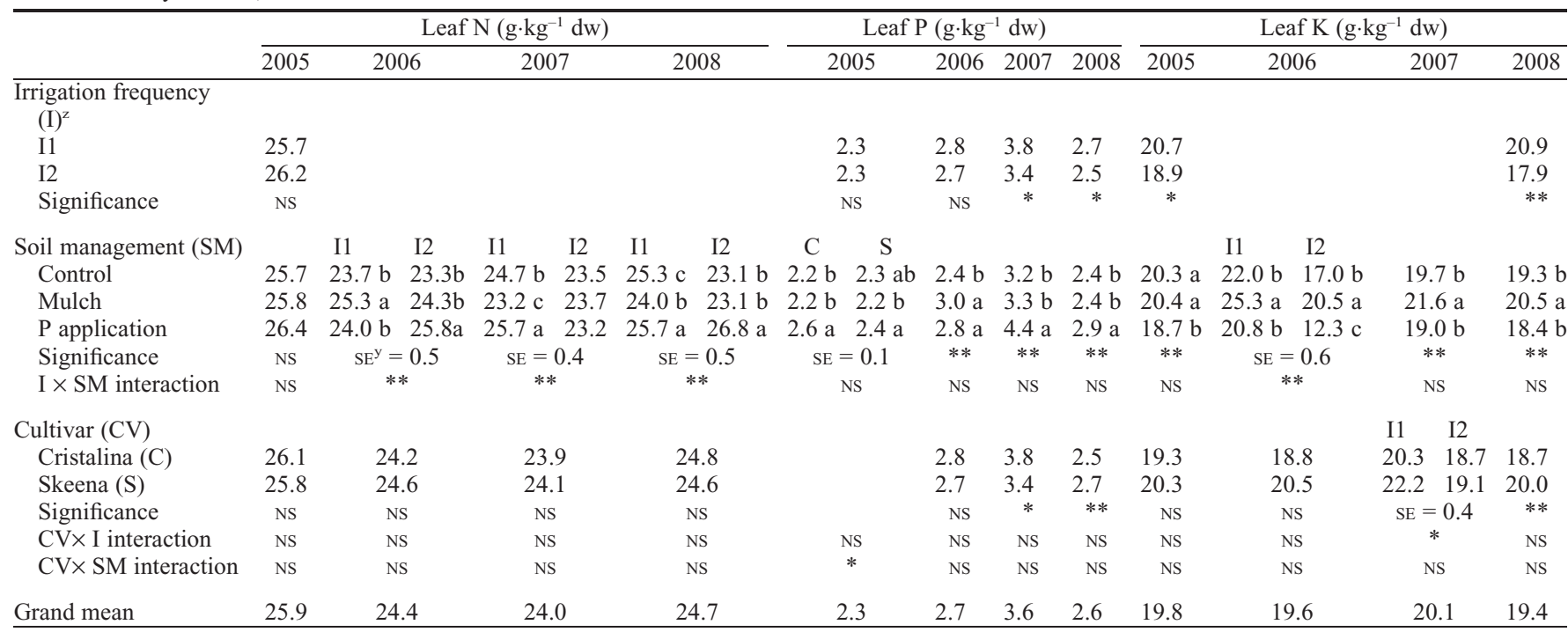

${ }^{\mathrm{z}}$ Irrigated four times daily (I1) or once every $2 \mathrm{~d}$ (I2) with the same quantity of water.

${ }^{y}$ When interactions are significant, SE of the interaction indicated.

$*$,**Means significantly different at $* P \leq 0.05$ or $* * P \leq 0.01$ or not significantly different (NS). For soil management treatments, means Ns when followed by the same letter.

$\mathrm{dw}=$ dry weight.

Table 2. Average harvested yield as affected by irrigation frequency, soil management treatment and sweet cherry cultivar during the period of initiation of fruiting, 2006 to 2008.

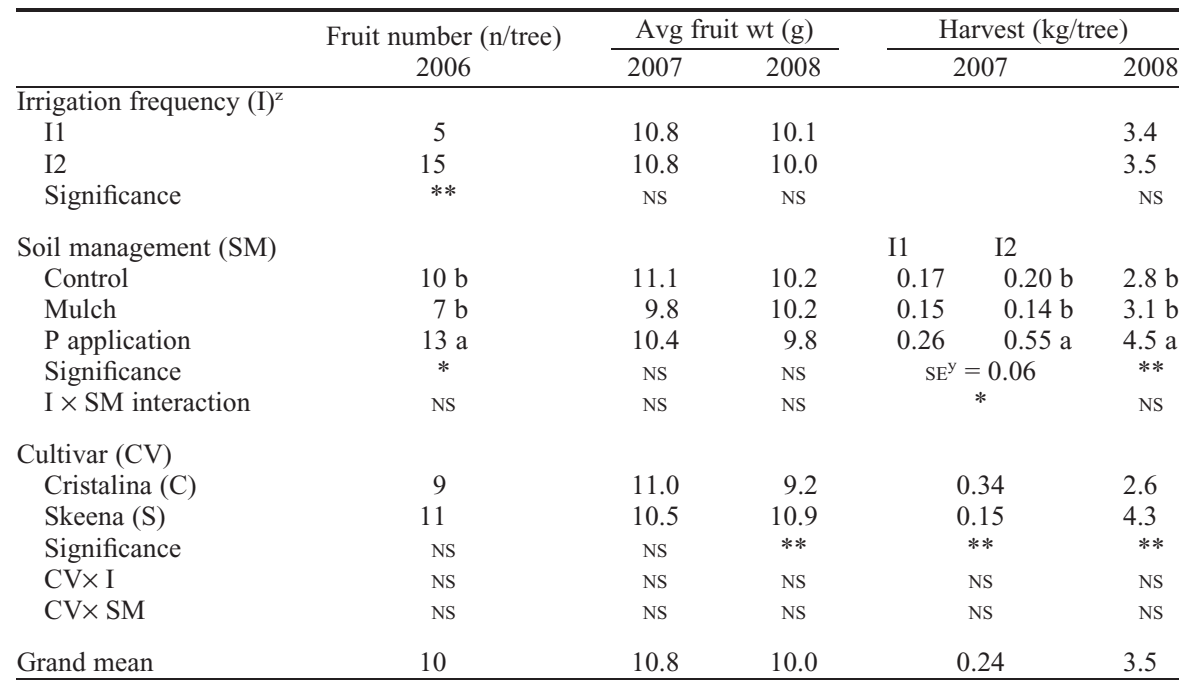

${ }^{\mathrm{z}}$ Irrigated four times daily (I1) or once every $2 \mathrm{~d}$ (I2) with the same quantity of water.

${ }^{\mathrm{y}}$ When interactions are significant, SE of the interaction indicated.

*, **Means significantly different at $* P \leq 0.05$ or $* * P \leq 0.01$ or not significantly different (NS). For soil management treatments, means Ns when followed by the same letter.

$\mathrm{P}=$ phosphorus.

fruit crop was strongly influenced by irrigation treatments (Table 3) with effects such as advanced maturity, increased SSC, and darker color paralleling fruit quality changes in deciduous fruit trees subjected to deficit irrigation (Naor, 2006). Apple trees undergoing deficit irrigation, however, frequently have increased fruit firmness and reduced fruit size (Behboudian et al., 1998), neither of which was observed for these cherries. Few studies have reported the consequences of deficit irrigation on quality of cherry fruit; although one of the few, by Marsal et al. (2009), identified advanced harvest maturity in the next year as the major fruit quality effect of reducing irrigation by $50 \%$ postharvest. Most of the other cherry quality effects measured in our study (decreased TA and stem pull force and increased phenolic composition for fruit from I2- relative to I1-irrigated trees) are associated with increased fruit maturity and are consistent with the importance of water stress in affecting cherry maturity. The least stressful irrigation treatment (I1) was associated with higher accumulations of $\mathrm{N}, \mathrm{P}$, and $\mathrm{K}$ in cherry fruit, which for $\mathrm{P}$ and $\mathrm{K}$ is consistent with increases observed in their respective leaf concentration.

Soil management. The effects of soil management on TCSA varied with irrigation treatment with trees grown with mulch larger than trees in untreated control treatments at I1 but not at I2 (Fig. 2). In general, mulching did not increase soil moisture content relative to control treatments. On only two of 33 measurement times was soil moisture content increased by mulching relative to control at I2 but not I1(data not shown). Soil moisture regime was affected more by irrigation frequency than by mulching.

Soil management treatments consistently affected leaf $\mathrm{P}$ and $\mathrm{K}$ but not leaf $\mathrm{N}$ concentrations (Table 1). P fertigation resulted in higher leaf $\mathrm{P}$ concentrations. although values were not significantly different for leaves from mulched trees in 2006 and for control 'Skeena' trees in 2005 when there was a significant cultivar by soil management interaction. Leaf $\mathrm{K}$ concentration was higher for mulched trees throughout the study relative to leaves from P-fertigated and control (except $2005)$ trees. Soil management treatments had no consistent effects on leaf $\mathrm{N}$ concentration, a likely consequence of the same $\mathrm{N}$ fertigation regime being applied throughout the experimental block.

The initiation of fruit production was affected most by $\mathrm{P}$ fertigation relative to the other tested soil management treatments. Fruit number in 2006, tree yield at I2 irrigation in 2007 , and averaged over both irrigation treatments in 2008 was higher than control and mulched trees (Table 2). Similarly, P application most affected quality of the first significant crop in 2008 with indications that harvest may have been delayed for this treatment 
Table 3. Average fruit quality characteristics of first significant crop (2008) as affected by irrigation frequency, soil management treatment, and sweet cherry cultivar.

\begin{tabular}{|c|c|c|c|c|c|c|c|c|c|c|}
\hline & \multirow{2}{*}{$\begin{array}{l}\text { Titratable } \\
\text { acidity }\end{array}$} & \multirow{2}{*}{$\begin{array}{c}\text { Soluble } \\
\text { solids (\%) }\end{array}$} & \multirow[b]{2}{*}{ Color $^{\mathrm{x}}$} & \multirow{2}{*}{$\begin{array}{l}\text { Firmness } \\
(\mathrm{g} / \mathrm{mm})\end{array}$} & \multirow{2}{*}{$\begin{array}{c}\text { Total } \\
\text { splits }(\%)\end{array}$} & \multirow{2}{*}{$\begin{array}{l}\text { Stem pull } \\
\text { force }(\mathrm{g})\end{array}$} & \multicolumn{3}{|c|}{ Fruit minerals (mg/100 g FW) } & \multirow{2}{*}{$\begin{array}{c}\text { Total phenolics } \\
\left(\mathrm{mg} \cdot \mathrm{g}^{-1} \mathrm{dw}\right)\end{array}$} \\
\hline & & & & & & & $\mathrm{N}$ & $\mathrm{P}$ & $\overline{\mathrm{K}}$ & \\
\hline \multicolumn{11}{|c|}{ Irrigation frequency $(\mathrm{I})^{\mathrm{z}}$} \\
\hline I1 & 12.3 & 18.5 & 3.9 & 325 & 1.9 & 0.79 & 214 & 29.5 & 235 & 1.17 \\
\hline $\mathrm{I} 2$ & 10.7 & 19.5 & 4.1 & 307 & 1.8 & 0.73 & 182 & 27.9 & 213 & 1.28 \\
\hline Significance & $* *$ & $* *$ & $*$ & $* *$ & NS & $*$ & $*$ & * & $* *$ & $* *$ \\
\hline \multicolumn{11}{|c|}{ Soil management (SM) } \\
\hline Control & 12.1 & $19.3 \mathrm{a}$ & $4.1 \mathrm{a}$ & 313 & 1.7 & $0.71 \mathrm{~b}$ & $196 \mathrm{ab}$ & $28.2 \mathrm{~b}$ & 223 & 1.25 \\
\hline Mulch & 12.1 & $19.1 \mathrm{a}$ & $4.0 \mathrm{a}$ & 313 & 2.1 & $0.75 \mathrm{ab}$ & $189 \mathrm{~b}$ & $28.0 \mathrm{~b}$ & 233 & 1.25 \\
\hline $\mathrm{P}$ application & 12.0 & $18.6 \mathrm{~b}$ & $3.8 \mathrm{~b}$ & 321 & 1.7 & $0.82 \mathrm{a}$ & $214 \mathrm{a}$ & $30.4 \mathrm{a}$ & 222 & 1.20 \\
\hline Significance & NS & $* *$ & $* *$ & NS & NS & $*$ & $*$ & $* *$ & NS & NS \\
\hline \multicolumn{11}{|l|}{ Cultivar (CV) } \\
\hline Cristalina (C) & 10.6 & 17.9 & 3.9 & 331 & 1.0 & 0.87 & 202 & 25.9 & 211 & 1.11 \\
\hline Skeena $(\mathrm{S})$ & 12.4 & 20.1 & 4.0 & 301 & 2.6 & 0.65 & 195 & 31.6 & 237 & 1.34 \\
\hline Significance & $* *$ & $* *$ & NS & $* *$ & $* *$ & $* *$ & NS & $* *$ & $* *$ & $* *$ \\
\hline Grand mean & 12.1 & 19.0 & 4.0 & 316 & 1.8 & 0.76 & 200 & 28.9 & 226 & 1.23 \\
\hline
\end{tabular}

Irrigated four times daily (I1) or once every $2 \mathrm{~d}$ (I2) with the same quantity of water.

y Units $\mathrm{mL} \mathrm{NaOH} / 10 \mathrm{~mL}$ of juice.

${ }^{\mathrm{x}}$ Michigan State color chart 1 to 5 scale.

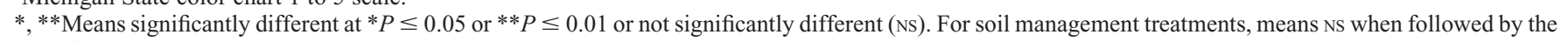
same letter.

$\mathrm{FW}=$ fresh weight; $\mathrm{dw}=$ dry weight; $\mathrm{P}=$ phosphorus.

(decreased SSC and color and increased stem pull force of harvested fruit) relative to the other soil management treatments (Table 3). Like with leaf $\mathrm{P}$, fruit $\mathrm{P}$ concentration was increased relative to control and mulched soils by $\mathrm{P}$ fertigation. Fruit $\mathrm{N}$ concentration was also higher but only relative to fruit from mulched trees.

Surface application of organic mulches can improve initial growth and yield of highdensity apple orchards on dwarfing rootstocks, which has been attributed to improved nutrient and water availability (Neilsen et al., 2004b) and increased soil biological activity (Forge et al., 2003). Observations from our current study suggest that application of mulch improved vigor of sweet cherry on the dwarfing rootstock Gisela 6 only under highfrequency irrigation indicating the benefits of mulching very coarse-textured soils, like in this study, is secondary to use of optimum irrigation strategies. The improved water retention capacity provided by a surface layer of coarse bark mulch was apparently inadequate to overcome the limited water-holding capacity of sandy loam soils irrigated once every $2 \mathrm{~d}$ (I2). The increased leaf K concentrations of cherry trees grown with the bark mulch treatment were of little practical significance because all $\mathrm{K}$ values were within the middle of the broad adequacy range for sweet cherry of 10 to $30 \mathrm{~g} \mathrm{~K} / \mathrm{kg}$ dw recommended by Hanson and Proebsting (1996). Increased leaf K concentration has frequently been a reported consequence of mulch application and attributed to the $\mathrm{K}$ content of the mulch (Neilsen et al., 2003).

It has been generally reported that sweet cherry seldom responds to applications of $\mathrm{P}$ under field conditions (Hanson and Proebsting, 1996). Consistent with these views, an earlier study found 'Lapins' sweet cherry on Gisela 5 rootstock unresponsive to fertigated $\mathrm{P}$ applied through sprinkler systems, which failed to increase leaf and fruit $\mathrm{P}$ concentration or to meaningfully affect tree performance (Neilsen et al., 2004a). In contrast, P fertigation through drip irrigation systems in our current study increased leaf and fruit $\mathrm{P}$ concentration and stimulated initial yield of 'Cristalina' and 'Skeena' on Gisela 6 rootstock. These results are consistent with recent research indicating yield response of five different apple cultivars to $\mathrm{P}$ fertigated annually through drip irrigation systems (Neilsen et al., 2008). Drip systems tend to concentrate root development close to the soil surface and emitter location, increasing the likelihood of fruit trees responding to fertigated nutrients (Neilsen et al., 1999). The P-stimulated increase in yield for dripfertigated sweet cherry was associated with delayed fruit maturity implying fruit harvest could have been later, allowing more time for the evolution of fruit characteristics, including an increase in fruit size. $\mathrm{P}$ application was thus beneficial in initiation of fruit reproduction as observed earlier with apple flowering (Neilsen et al., 1990). Whether this effect is persistent requires further assessment when these trees produce larger crops.

Cultivar. Throughout the study, 'Skeena' was more vigorous than 'Cristalina' with differences measurable from 2005 to 2008 when averaged over irrigation and soil management treatments (Fig. 3). 'Cristalina' was, however, more sensitive to water stress than 'Skeena' as indicated by a significant correlation between the relative rate of TCSA increment during the 2007 growing season and average soil moisture volumetric content for 'Cristalina' (Fig. 4A) but not 'Skeena' (Fig. 4B). A soil moisture content averaging $\approx 10 \%$ over the surface 20 $\mathrm{cm}$ depth throughout the growing season was associated with smaller increases in TCSA (and hence, canopy volume) of 'Cristalina'.

There were no differences in leaf $\mathrm{N}$ concentration and inconsistent differences in leaf $\mathrm{P}$ concentration between the cultivars over the first four growing seasons (Table 1). Leaf $\mathrm{P}$ concentration was increased for 'Cristalina' relative to 'Skeena' in 2007 and in 2005 for Pfertigated trees but in 2008, leaf P was decreased relative to 'Skeena'. There were no differences between cultivars in 2006. Leaf K concentration, when affected, was increased for 'Skeena' relative to 'Cristalina', both in 2007, for I1-irrigated trees (significant cultivar $\times$ irrigation interaction) and in 2008 averaged over all treatments.

'Skeena' outyielded 'Cristalina' in 2008, the largest crop year, when average fruit size was also larger (Table 2). There were numerous differences between fruit properties of the cultivars in 2008. 'Skeena' fruit had increased TA, SSC, total fruit splits, and concentrations of $\mathrm{P}, \mathrm{K}$, and total phenolics (Table 3). In contrast, 'Skeena' fruit was softer and was attached less firmly to the tree as indicated by a lower stem pull force at harvest than 'Cristalina'.

The limited research on irrigation specific to sweet cherries has been previously noted (Hanson and Proebsting, 1996). Our results would suggest that there are likely differences in cultivar response to irrigation regimes, specifically that 'Cristalina' is more sensitive to water stress in establishment years than 'Skeena'. It is likely that restricted N-P-K nutrition was not the causal factor in reduced vigor of 'Cristalina' because, although there were minor statistical differences in leaf $\mathrm{P}$ and $\mathrm{K}$ between cultivars, none of the changes resulted in less than adequate leaf concentrations (BCMAL, 2007). The experimental study period represented the transition between vegetative and fruiting growth. As indicated previously, the 2007 crop was reduced by both winter cold the end of Nov. 2006 and frost damage occurring between side green and early tight cluster resulting in low yield for both cultivars but greater yield for 'Cristalina'. As a result, most of the yield during the study occurred in 2008 with higher yield for 'Skeena' relative to 'Cristalina', a possible consequence of 'Cristalina's lack of self-fertility 


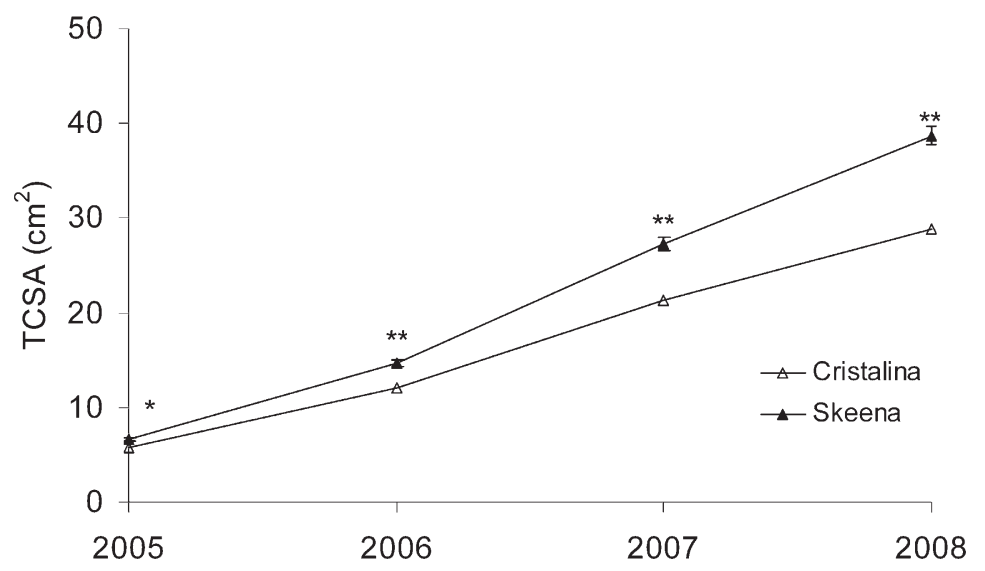

Fig. 3. Average trunk cross-sectional area as affected by cultivar at the end of each growing season, 2005 to 2008. Irrigation treatments include I1 (4× daily) or I2 (every second day) applying the same quantities of water. Cultivar SE indicated on the top curve.

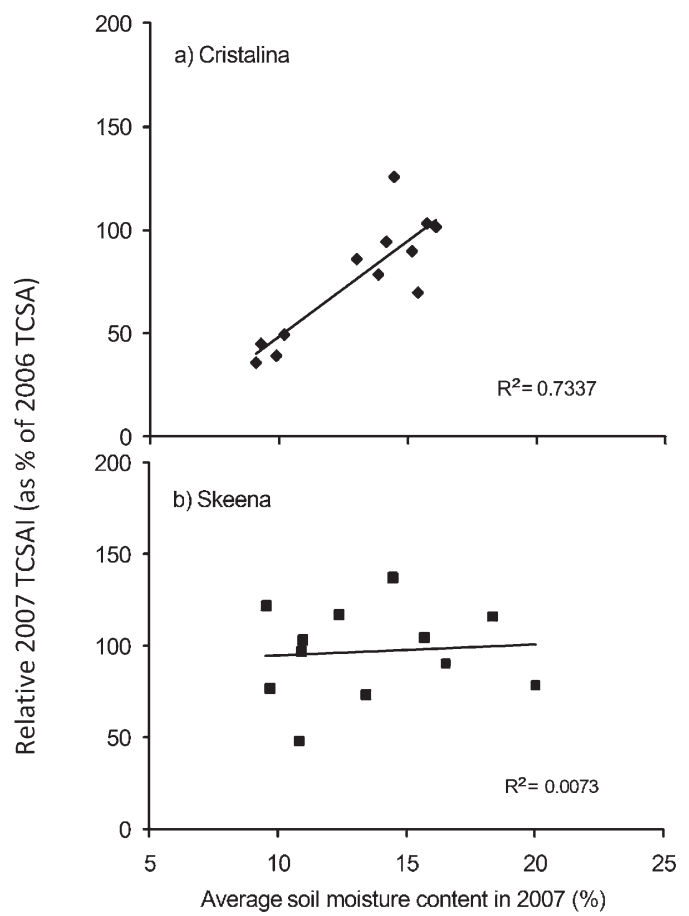

Fig. 4. Relative trunk cross-sectional area increment (TCSAI) in 2007 for (A) 'Cristalina' and (B) 'Skeena' as related to average soil moisture content at 0 - to $20-\mathrm{cm}$ depth throughout 2007 ( $\mathrm{n}=12)$.

(Kappel et al., 1998). The many differences in fruit properties were measured in a single year at much less than maximum crop load and would need to be confirmed over several cropping years as a result of the known high annual variability of cherry properties (Proebsting and Mills, 1981). Both 'Cristalina' and 'Skeena' have been reported to have low pedicel removal force and moderate firmness in rankings of Summerland cultivars (Wirch et al., 2009). Our data indicate fruit from 'Skeena' can be softer with reduced pedicel retention force relative to 'Cristalina' fruit.

\section{Conclusions}

The design of this experiment allowed an assessment of the effects of irrigation frequency and several soil management strategies on the establishment and initiation of fruiting for the new sweet cherry cultivars Skeena and Cristalina planted on the promising new dwarfing rootstock, Gisela 6. On the coarse-textured soil at this site, altering irrigation frequency to allow multiple, daily applications of small irrigation amounts (pulsed irrigation) sustained an improved soil moisture regime and increased tree vigor during the transition of trees from vegetative to reproductive growth. Negation of factors inhibiting early tree vigor is valuable, even for planting systems involving the ultimate establishment of more closely planted, smaller cherry trees on dwarfing rootstock, because it is desirable to have rapid development of the fruiting canopy by avoiding excessive early growth retardation. The avoidance of water stress to maximize prefruiting vegetative growth was best achieved by pulsed irrigation (I1) because growth benefits, which might be anticipated by mulching, were observed only at I1. Irrigation frequency had no effects on yield of the first major crop in 2008 despite the range in tree vigor between irrigation treatments and concerns that excessive vigor can delay the onset of fruiting. Once fruiting was established in 2008, water stress accelerated crop maturity.

Soil management strategies had minor effects on tree vigor relative to increasing irrigation frequency. Annual, bloom time $\mathrm{P}$ fertigation accelerated the onset of fruiting and fruit yield in 2008 suggesting $P$ fertigation is desirable for establishing high-density sweet cherry orchards. Mulching, which would normally be expected to reduce the detrimental consequences of water stress, was only effective with the pulsed irrigation regime, which improved water retention throughout the surface $0.2 \mathrm{~m}$ of the soil profile rather than the immediate surface mulch layer.

It can be difficult to predict the performance of new sweet cherry cultivars to horticultural management because the emphasis of most breeding programs is the development of cultivars with desirable (and often distinctive) fruit properties. Hence, comparative studies such as these are valuable for providing an insight into what may affect the growth behavior of different cultivars in the field. In this regard, the greater vigor of 'Skeena' relative to 'Cristalina' on Gisela 6 rootstock suggested a greater sensitivity to water stress of 'Cristalina' and a need to optimize irrigation of 'Cristalina' before the initiation of fruiting. Future management challenges for 'Skeena' include low pedicel retention because these values are low relative to 'Cristalina' and both cultivars were already considered to have low values of these properties relative to other commercial cultivars. It is, however, necessary to confirm these findings on fruit quality in future years as these trees enter a period of higher crop load stress.

\section{Literature Cited}

Barber, S.A. 1984. Soil nutrient bioavailability. A mechanistic approach. John Wiley \& Sons, New York, NY.

Behboudian, M.H., J. Dixon, and K. Pothamshetty. 1998. Plant and fruit responses of lysimetergrown 'Braeburn' apple to deficit irrigation. J. Hort. Biotechnol. 73:781-785.

British Columbia Ministry of Agriculture and Lands (BCMAL). 2007. Integrated fruit production guide for commercial fruit growers. Interior districts, Victoria, BC, Canada.

Forge, T.A., G. Neilsen, E. Hogue, and D. Neilsen. 2003. Effects of organic mulches on soil microfauna in the root zone of apple: Implications for nutrient fluxes and functional diversity of the soil food web. Appl. Soil Ecol. 22: 34-54.

Hanson, E.J. and E.L. Proebsting. 1996. Cherry nutrient requirements and water relations, $\mathrm{p}$. 243-257. In: Webster, A.D. and N.E. Looney (eds.). Cherries: Crop physiology, production and uses. CAB Intl., Oxford, UK.

Kappel, F., W.D. Lane, R. MacDonald, K. Lapins, and H. Schmidt. 1998. 'Santina', 'Sumpaca Celeste' and 'Sumnue Cristalina' sweet cherries. HortScience 33:1087-1089. 
Lang, G.A. 2009. High tunnel tree fruit production: The final frontier. HortTechnology 19:50-55.

Marsal, J., G. Lopez, A. Arbones, M. Mata, X. Vallverdu, and J. Girona. 2009. Influence of post-harvest deficit irrigation and pre-harvest fruit thinning on sweet cherry (cv New Star) fruit firmness and fruit quality. J. Hort. Biotechnol. 84:273-278.

Naor, A. 2006. Irrigation scheduling and evaluation of tree water status in deciduous orchards. Hort. Rev. (Amer. Soc. Hort. Sci.) 32:111-165.

Neilsen, G., F. Kappel, and D. Neilsen. 2004a. Fertigation method affects performance of 'Lapins' sweet cherry on Gisela 5 rootstock. HortScience 39:1716-1721.

Neilsen, G., F. Kappel, and D. Neilsen. 2007. Fertigation and crop load affect yield, nutrition, and fruit quality of 'Lapins' sweet cherry on Gisela 5 rootstock. HortScience 42:14561462.

Neilsen, G.H. and J. Yorston. 1991. Soil disinfection and monoammonium phosphate fertilization increase precocity of apples on replant problem soils. J. Amer. Soc. Hort. Sci. 116: 651-654.

Neilsen, G.H., E.J. Hogue, and P. Parchomchuk. 1990. Flowering of apple trees in the second year is increased by first-year P fertilization. HortScience 25:1247-1250.

Neilsen, G.H., D. Neilsen, and F. Peryea. 1999. Response of soil and irrigated fruit trees to fertigation or broadcast application of nitrogen, phosphorus and potassium. HortTechnology 9: 393-401.
Neilsen, G.H., E.J. Hogue, T. Forge, and D. Neilsen. 2003. Surface application of mulches and biosolids affect orchard soil properties after 7 years. Can. J. Soil Sci. 83:131-137.

Neilsen, G.H., E.J. Hogue, D. Neilsen, and T. Forge. 2004b. Use of organic applications to increase productivity of high density apple orchards. Acta Hort. 638:347-356.

Neilsen, G.H., D. Neilsen, P. Toivonen, and L. Herbert. 2008. Annual bloom-time phosphorus fertigation affects soil phosphorus, apple tree phosphorus nutrition, yield, and fruit quality. HortScience 43:885-890.

Neilsen, G.H., P. Parchomchuk, R. Berard, and D. Neilsen. 1997. Irrigation frequency and quantity affect root and top growth of fertigated 'McIntosh' apple on M.9, M.26 and M.7 rootstock. Can. J. Plant Sci. 77:133-139.

Núñez-Elisea, R., H. Cahn, L. Caldeira, and C. Seavert. 2004. Effect of a synthetic fabric row cover on soil moisture content, growth and fruiting of young sweet cherry trees (Prunus avium L. cv. 'Regina'/Gisela 6). HortScience 39:850 (abstr.).

Parchomchuk, P., R.C. Berard, and T.W. Van der Gulik. 1996. Automated irrigation scheduling using an electronic atmometer, p. 1099-1104. In: Camp, C.R., E.J. Sadler, and R.E. Yoder (eds.). Evapotranspiration and irrigation scheduling. Amer. Soc. Agr. Engn. Proc. Intl. Conf., San Antonio, TX.

Proebsting, E.L. and H.H. Mills. 1981. Effects of season and crop load on maturity characteristics of 'Bing' cherry. J. Amer. Soc. Hort. Sci. 106:144-146.
Robinson, T.L., R.L. Anderson, and S.A. Hoying. 2008. Performance of Gisela ${ }^{\circledR}$ rootstocks in six high density sweet cherry training systems in the Northeastern United States. Acta Hort. 795:245-253.

SAS. 1989. SAS/STAT. User's guide. Vers. 6, Vol. 2. SAS Inst., Cary, NC.

Silber, A., G. Xu, I. Levkovitch, S. Soriano, A. Bilu, and R. Wallach. 2003. High fertigation frequency: The effects on uptake of nutrients, water and plant growth. Plant Soil 253:467-477.

Topp, G.C. and W.D. Reynolds. 1998. Time domain reflectometry: A seminal technique for measuring mass and energy in soil. Soil Tillage Res. 47:125-132.

Whiting, M.D., G.A. Lang, and D. Ophardt. 2005. Rootstock and training system affect sweet cherry growth, yield and fruit quality. HortScience 40:582-586.

Wirch, J., F. Kappel, and P. Scheewe. 2009. The effect of cultivars, rootstocks, fruit maturity and gibberellic acid on pedicel retention of sweet cherries (Prunus avium L.). J. Amer. Pomol. Soc. 63:108-114.

Wittneben, U. 1986. Soils of the Okanagan and Similkameen Valleys. Ministry of Environment Technical Report 10. British Columbia Soil Survey, Report 52, Victoria, BC, Canada.

Yin, X., C.F. Seavert, J. Turner, R. Núñez-Elisea, and H. Cahn. 2007. Effects of polypropylene groundcover on soil nutrient availability, sweet cherry nutrition, and cash costs and returns. HortScience 42:147-151. 